\title{
Reflections on Monetary and Fiscal Policies and Economic Growth in India (RMFPEGI)
}

\author{
Sudhansh Kumar Sharma and Beena Sharma
}

\begin{abstract}
Monetary and Fiscal policies have powerful influence on the pace and pattern of economic growth of a nation. In a developing country like India the major concern of economic policy needs to be diverted and accelerated on the rate of development and in this process, monetary and fiscal policies have a strategic role to play. In this paper an attempt has been made to examine some of the pertinent issues and give policy suggestions for making an efficient use of monetary and fiscal measures to accelerate economic growth.
\end{abstract}

Index Terms-Long Term Fiscal Policy (LTFP), Reserve Bank of India (RBI), government's financing plans, eleventh plan.

\section{INTRODUCTION}

At the outset, it needs to be clarified that technically fiscal policy constitutes the government's management of its finances while monetary policy concerns largely the country's central bank, the Reserve Bank of India. Yet, the course of fiscal policy also determines the directions of monetary policy. "Even as prudence in financial management demands that fiscal policy should be turned to the needs of monetary control. However, all over the world, the institution entrusted with the exercise of monetary authority is constrained to follow the dictates of fiscal policy. RBI can only voice periodically, this itself has become a meaningless routine its unhappiness over growth in reserve money largely arising out of the Central Government's massive recourse to deficit financing and manage as best as it can a situation created by New Delhi's fiscal excesses" [1]. The RBI has control over states budgetary deficits through the over draft regulation scheme, but has none ever central deficit financing. Hence, "the introduction of a system of monetary targeting, mutually agreed upon between the Government and RBI as suggested by the Governor, should be implemented. To affect co-ordination between fiscal and monetary policies it was necessary to reach yearly agreements on the extent of expansion in Reserve Bank credit to the Government. This he said, would set a limit on the extent of fiscal deficit and its monetization and there by provide greater maneverability to the monetary authorities to regulate the volume of money"[2]. Fiscal economists have emphasized resources mobilisation for development needs in economics like India as being the primary task of fiscal policy. Raja Chelliah observes that, "the fundamental principle underlying the tax structure (of a developing

Manuscript received June 5, 2014; revised August 22014.

The authors are with the Department of Commerce, Jagdish Saran Hindu Post Graduate College, Amroha, Uttar Pradesh - 244221 India (e-mail sudhansh.1957@gmail.com, sube357@yahoo.co.in). economy like India) should be the principle of mobilization of the economic surplus... and (Channelling) it into investment without, in the process, destroying or gravely restricting its occurrence" [3]. The Finance Minister presented to the parliament a long term fiscal policy on 19th December, 2011 which was co-terminus with the Eleventh Five years 2007-2012. This would provide a future perspective as well as impart a measure of stabilities to the Government's economic policy ticket, besides being an indispensable underpinning for the plan effort and strategy.

\section{MONETARy POLICY In DEVEloping COUNTRY LiKE INDIA}

The primary role of monetary policy in developing country like India is to facilitate economic growth with a reasonable stability in prices. Balance of payments is more a constraint than an objective; and it makes sense to interpret stability broadly as control of inflation or keeping the general price-level from rising by more than a few percentage points per year. Regarding a rise of this order as reasonable has no intrinsic merit although it is sometimes argued that it is necessary to permit required changes in relative prices. In truth, it is only recognition of reality as in practice very few countries manage to do as well. But once more and more countries achieve low rates of inflation, it should be feasible to aim at even lower rates; and it has to be regarded as a major achievement of recent years that it is no longer considered unthinkable to aim at a zero rate of inflation on an average such as what has prevailed in fact over much of the industrial era. For achieving stability, it is generally considered necessary to keep the growth of money supply in step with the demand for it, which is assumed to be uniquely related to national income, at any rate over the medium-term and when due allowance is made for secular changes such as those arising from growing monetization of the economy. This line of reasoning has led in practice to some version of monetary targeting in developed as well as developing countries, often encouraged by stabilization programs initiated under IMF or World Bank auspices. As early as 1953, an IMF mission to India had recommended such a practice which has later found support also from the Chakrabarty Committee set up to review the working of monetary policy in India. Despite the general support and indeed practice of monetary targeting as a necessary instrument for achieving and maintaining stability, criticism of this approach is also heard often. Some of the criticism of monetary targeting, however, is certainly beside the mark. It can be easily shown, for example, that the velocity of circulation of money or the income elasticity of demand for money is not constant over relatively short periods of time. But there is some relationship which can be 
calculated as being reasonably stable over a period and it can be assumed as what is likely to prevail in the near future. No one in the realm of practical politics recommends a strict monetary target. Most such targets are set as a range, and there is always the admonition that monetary targets must be kept under review. The Chakrabarty Committee thus speaks of monetary targets with a feedback [4].

What needs perhaps to be emphasized is that monetary targeting should not lead to constant tinkering with monetary policy so as to counteract every deviation from the target set. Such tinkering or fine-tuning can be destabilizing and counterproductive. But systematic and large deviations from monetary targets already set should serve as a signal for reviewing policy. The criticism that monetary targeting while necessary is not sufficient is of course valid, and it was echoed long ago by Joan Robinson. Monetary targeting makes sense only if the permissible increase in money supply is correctly distributed between the legitimate claims of the budget, the private sector and the country's need for foreign exchange reserves. But surely advocates of monetary targeting are aware of this and, in fact, monetary or credit budgeting is generally attempted on a disaggregated basis. Indeed, it can be claimed as a merit of monetary targeting that it focuses attention on a proper mix of budgetary, monetary and foreign exchange policy. It is not easy to apportion the permissible increase in money supply between the budget, the private sector and the external sector. As an economy grows and its external trade expands, it will need more foreign exchange reserves and this should have the first priority in the allocation of the permissible increase in money supply. Much of the debate centers on allocation between the public and the private sector. The bias in developed countries now is to under play the needs of the public sector. In most developing countries, there is a tendency to put the needs of the public sector before those of the private sector- witness the Chakrabarty Committee which lists among the functions of the Reserve Bank the provision of the urgent needs of the Government without any reference to the competing claims of the private sector. The Reserve Bank cannot perform its developmental role properly unless it assumes responsibility for the establishment of a diversified financial structure that supports the borrowing and lending needs of the private sector. Part of this responsibility can be discharged by the Central Bank directly providing resources to credit institutions that support the private sector. But if any a priori rule about how much of a central bank's assets should be in foreign exchange reserves and how much in claims on Government and how many in claims on the private sector including claims on developmental financial institutions can be laid down. The relative importance of the public and private sector in national productive investment should be borne in mind and some room must be left for the accumulation of foreign exchange reserves.

It is difficult to prescribe a precise boundary for money when there are so many near substitutes for money. It is also true that money which is easy to control such as reserve money may not be in the most stable relationship with national money income. But the point is that as long as monetary targeting is used only as a significant indicator and not as a rigid framework, there is nothing wrong in watching trends in money supply as variously defined and interpreting the trends in the light of all the facts currently available. Indeed, any sensible economic analysis which must precede any policy decision must include the analysis of monetary and financial developments and analysis implies at least in part, comparison with some standard or target. The criticism of monetary targeting is the one which starts by pointing out those monetary targets at best are intermediate targets and the policy response to them has to be discretionary rather than rule based. If the objective is price stability and external viability, one can look simply at trends in prices and balance of payments and analyze them and wield such instruments of policy as may appear relevant in the light of this analysis. Indeed, concentrating too much on an intermediate target like stocks of money is not just second best; it may even be misleading as it may narrow the focus on monetary factors and lead to the overlooking of other factors. Current pressures on prices, for example, may be the result of interruptions in key supplies, or due to some external shock, or due to wages exceeding productivity increases, rather than the result of excessive demand resulting from excessive credit creation. A strictly monetary response in such cases, may be inadequate or of little use. One should speak of monetary targeting only as a minor key. There is a great deal of merit in this line of reasoning. But let us also remember that it only reminds us that mere analysis of monetary trends and setting of monetary targets may not be sufficient. It does not say they are not necessary. Undoubtedly, it is useful to remind ourselves that the starting point should be the final goals of price stability and B.O.P stability and not some intermediate and approximate indicators such as money supply which may be relevant as a part of the analysis as well as of the cure but are never the full story. There is another valid criticism of monetary targeting which is of an analytical character, viz; that for an indication of inflationary pressures and their cure, it is better to think in terms of the familiar Keynesian categories of budget deficits, current account deficits, and the difference between private savings and investments. In other words, the significant question is not the allocation of the permissible increase in money supply between the public and the private sector but the allocation of available savings, or who crowds out whose investment and how. Merely talking of money creation or money supply obscures this fact.

It is important to emphasize that if the basic budgetary position is not right, it cannot be set right by action on the fiscal front itself. But if the fiscal front is set right, monetary policy can be relaxed. Given fiscal prudence, it is of little avail. In most developing countries, inflationary pressures arise from the operations of the budget rather than from any upsurge in credit to the private sector. Monetary policy cannot really correct this situation. It can at best bring home more effectively the consequences of important public finance. Whether it does so through rocketing interest rates or rising prices is not of much comfort or consequences except perhaps to ideologues. It has to be remembered that where interest rates are controlled or administered and where the central Bank virtually underwrites budgetary deficits as is the case in most all developing countries, the savings and investment approach and the monetary targeting approach 
come to virtually the same thing. The monetary approach has at least the advantage that monetary data are more readily available so that they are a better or more feasible basis for planning and monitoring. Each exercise of activist monetary policy becomes irreversible in practice because as long as budgetary policy is inflationary, any relaxation of monetary restraint will be open to criticism. The result is that there is a kind of Ratchet effect whereby interest rates, reserve requirements and all the rest keep going up and monetary instruments in effect become blunt and arbitrary in their impact on private investment and activity. The major responsibility for maintaining stability in developing countries is considered as that of fiscal policy and that monetary policy at best has a subordinate role. Its actions, therefore, should be muted and more self-restrained. There is no alternative to the good sense of the people in power and the pressure of public opinion. It might nevertheless, be desirable at least to try and set some norms for the Government budget and for debt management. Thus, as a minimum, there should be no borrowing to finance current expenditure. Commercial banks should not be forced to take up Government securities beyond a certain proportion of their liabilities and this proportion should not be changed except after relatively long intervals. This proportion is generally fixed in response to prudential considerations. It is also worth considering whether norms cannot be fixed for central Bank support for Government Securities - such norms are implicit in monetary targeting in any case, and it may be worthwhile to make them explicit over a number of years ahead. But in the ultimate analysis, norms are norms and cannot be binding particularly in countries where the market for Government securities outside the banking system is rather thin, and the credibility of norms will depend on how closely they are observed.

In some other monetary aspects, there has been a great deal of debate and experimentation with monetary programs in developing countries. Much of the debate and discussion has centered around programs prescribed by the IMF, the central part of which has been insistence on monetary targeting. So far as we see some practical value in monetary targeting, we cannot object to IMF programs in principle. It is not valid to criticize the IMF for any program of stabilization, such as the conflict in the short-run between growth and stability or the conflict between desirable social goals and budgetary restraint and so on. If there are better answers for resolving such conflicts, surely the countries concerned should know them better than the IMF. The IMF can be criticized for two things. First, its faith in monetary targeting was too absolute. Surely any transgression of monetary targets is or reason for reviewing policy, not for stopping IMF assistance and thus creating a further crisis of confidence. Second, and perhaps more important to begin with at any rate the Fund took to moralistic view towards developing countries only. It seems that even if difficulties arise for reasons beyond our control, we have to adjust as long as these difficulties or circumstances are not likely to be reversed. But surely this general argument could have been strengthened by advocating strongly that the adjustment can only be made sensibly over a period. The IMF of developed countries talked for a long time as financiers rather than as a body of world statesmen. But that is the politics of the world economy, which is unfortunately not likely to change. One moral of recent experience in developing countries that once inflation is allowed to accelerate, it is difficult to bring it under control except by strict monetary measures. Even when monetary measures like currency reform and total restructuring of prices are necessary, they would stick only if at the same time orthodox measures are taken to correct the budgetary imbalance and to rein- in the unions and the speculators. There is, in other words, no magic solution to hyperinflation any more than the problem of correctly guessing the changing needs for liquidity when high inflation rates are suddenly brought down. Experience shows that the demand for money often increases with stabilization so that unless this is met, a crisis may result causing much loss of output and employment. But it is not easy to guess the extent of the change in the demand for money correctly.

In many developing countries, the important feature to consideration is that of liberalization from a regime of extensive controls to greater reliance on market forces. This general shift has embraced not just the developed world or the socialist world but also many of the developing countries like India which have had a mixed pattern of ownership with a heavy bias in favor of public control or intervention. An interesting question in all these countries at the present juncture is the role that financial liberalization can play as part of the total process of liberalization and globalization. But difficult to generalize on a question like this where the institutional and other specifics of each country are of obvious importance. There is need for diversification among financial institutions and for a degree of deregulation and competition leading to greater financial innovations. Thus banks may be encouraged to go in for mortgage finance or long-term industrial finance; industrial banks, unit trusts and provident funds can also diversify their port folios, and indeed more private banks, private unit trusts or private industrial and other financial institutions should be encouraged. The spirit of liberalization will also imply that even public financial institutions, including the central Bank, should be freed from routine governmental intervention and so this should be reflected in appropriate managerial and constitutional structures. The financial institutions themselves should avoid policies and procedures which give too much discretionary powers to individual officers as well as for the Government. After all, abuses of power and corruption or politics and being over-burdened with too many objectives can do harm to financial institutions as much as they do in most other institutions. Developments in industrialized countries are of significance to developing countries and some of them may be profited by the later. At the same time, the policy-mix in developed countries has not yet settled down. As far as monetary policy is concerned, it can at best have a sub-ordinate and supporting role in both sets of countries. There is little reason to think that it can be more effective in one group of countries than in another. Economic logic often transcends institutional frontiers as well as national frontiers. There is a greater danger in developing countries and it is that of giving to the central Bank an exaggerated role under which it assumes rather hyper-active poses. It has to demonstrate to its masters that it 
is doing something. Actually, the central Bank cannot wash away the supply-side shocks. At the same time, it has a very important developmental role. It also has an important role in terms of analysis and advise on matters relating to inflation and balance-of-payments adjustments; and its part of advice can often best be transmitted by analysis of monetary and financial aggregates and by persuading governments to adopt procedures such as monetary target setting which facilitate focusing on the interactions between budgetary, monetary and foreign exchange policy [5].

\section{PRINCIPAL BENEFITS OF LTFP (LONG TERM FISCAL POLICY)}

According to the LTFP the principal benefits that may be anticipate from a long term perspective to fiscal policy are:

First, the long term fiscal policy will impart a definite direction and coherence to the sequence of annual budgets.

Second, successful economic management of our complex economy demands a greater role for rule-based fiscal and financial policy and less reliance on discretionary case by case administration of physical controls. Such an evolution will be greatly assisted by the long term fiscal policy.

Third, the growing maturity and complexity of our economy also calls for a much more integrated approach to economic policy and its management. "Effective co-ordination of different dimensions of economic policy, fiscal policy, monetary policy, industrial policy and trade policy will be facilitated by a long term perspective to policy making. The linkage between fiscal and monetary policy is particularly close as the Government's financing plans have a crucial bearing on the growth of money supply in the economy. Similarly, prudent monetary and credit policies are essential for sound fiscal management" [6].

Fourth, the long term fiscal policy is intended to serve as an effective vehicle for strengthening the operational linkages between the fiscal and financial objectives of the Eleventh Five year plan and the annual budgeting exercise to be conducted during the plan period. The Eleventh Plan lays down five years totals as targets for public sector expenditures and the sources of financing, including surpluses from current revenues, resources of public sector undertaking, additional resources mobilization various firms of domestic borrowing and net capital inflows from abroad. The long term fiscal policy will serve as a bridge between the five years financial targets of the Eleventh Plan and the annual budgets by providing an indicative, year-wise financial framework for fiscal policy.

\section{INADEQUACIES IN THE LTFP}

It seems that "some of the policy measures have been incorporated into the LTFP without adequate consideration of their economic rationale and likely effects, possibly due to time constraints and partly the lack of experience in formulating a LTFP due to the novelty of the idea. The LTFP should be taken as a starting point to formulate a rational fiscal policy [7].

On the negative side, one would mention the government's intention to eliminate exemptions and deduction in both personal and corporate income taxation. This could be interpreted in different ways one of which is that the Government is giving itself an option to resort to additional tax effort by means other than raising the rates. In any case, a study of LTFP would reveal that nowhere has the finance minister categorically stated, as in the case of personal tax rates, that he intends to keep the rates of corporate income unchanged for five years.

According to I.Z. Batty, it would therefore seem, that fresh incentives are required not much for generation saving but for directing it. In the past a substantial proportion of saving used to be in a physical form (Land, housing etc.) but in more recent times the share of financial savings (banks deposits, insurance etc.) has been steadily growing. Since financial savings are mobilisable while physical savings are not, what seems to be required is to faster the trend towards more financial savings. It seems that less drastic measures than a shift to expenditure tax can easily achieve this.

Finally, it would be an error to look for a complete and final pronouncement of policy in LTFP. This it is not. It only makes a beginning, through a decisive one, in that direction.

According to V. Char, in the case of wage and salary earners as well as several other fixed income group, dearness allowance to some extent may neutralize the increase in cost of living. But by the same token, incomes are inflated and salary earners are pushed into higher income brackets thereby increasing tax liability and reducing the allocating efficiency.

While there is welfare posturing in the LTFP, there are hardly any offbeat solutions for mobilizing resources for financing poverty alleviation and employment/generation programs. "The Government could still buttress such programs through an imaginative fiscal plan by means of levying a developmental poverty alleviation charge on some of the holy cows such as conspicuous agricultural incomes, the revenue from which could be directly earmarked for these programs without going into the consolidated Fund of India" [8]. As for agriculture being a state list subject, there is nothing to prevent the Union Government form getting state Governments to authorize the Centre, under Article 252 of the Constitution to administer such a change or levy on their behalf as they in fact did in the case of estate duty on agricultural land. Given the fact that the primary sector accounts for a predominant share of GNP the objective of making the tax structure income elastic cannot by achieved without progress in bringing large farm incomes into the tax net.

By this single measure "the Government has expressed courage of conviction in its own fiscal policy as one of the instruments for achieving stated economic objective. Also it marks a distinct land mark in professional fiscal management as well as sophistication in that area. And not the least important is the mitigation of capriciousness in Indian taxation simply evident in the consternation and concern on budget day" [9]. Essentially what LTFP does is to provide for the first time, a frame for financing the plan with its implications and to lay down certain policy directions. "In doing so it lifts the financing of Government expenditures out of the route of ad hoc maneuvering and puts it on a path towards reasonably well defined goals which are consistent with the historically evolving needs of the economy activity 
can now be carried on in an environment of relative stability and its impact on investment and growth is bound to be positive fiscal policy involves more than raising resources for the government sector" [10]. It comprises powerful instrument for influencing macro variable such is saving, investment the price level and costs as well as the allocation of resources and these must be employed the best advantage. Indeed, "a proper fiscal policy would stimulate growth and saving and these in turn would lead to a faster rate of growth of Government revenue" [11].

\section{Policy Suggestions}

The Planning commission is currently engaged in preparing the XIIth five year plan which would aim at a growth rate of 17.8 percent per annum for the plan period. The biggest fiscal challenge is to generate the required resources therefore in a non-inflationary manner. For this purpose, every effort should be made to substantially raise the tax GDP ratio. In particular, the share of direct taxes needs improvement through better enforcement, enlarging the pool of tax payers and reducing were justified the wide array of fiscal concessions. Larger revenues should also accused from indirect taxes arising from higher industrial production and plugging of loopholes for tax evasion.

Curbing growth in non-plan, non-developmental spending is essential, but all expenditures, plan or non-plan need vigorous and wide ranging scrutiny, to eliminate unproductive outlays. The restoration of fiscal balance between revenue receipts and expenditure would be a first step towards improved financial discipline. The public sector has to start getting better returns on its investment. Moderation in public sector borrowing and the budgetary deficit is urgently called for Reduction in defense expenditure, and properly monitoring it. Subsidies be reduced to minimum level, on public administration, there should be free on all new posts and new recruitments as well as on all vacancies, there is scope for further mobilization of savings but borrowing for meeting revenues deficits is limited for capital expenditure only.

While massive deficit spending if diverted to antipoverty programs should help reduce economic disparities somewhat, there is still the dancer of such diversion turning out to be counterproductive. A part from misuse of funds, what we have to consider in this context is the fact that productive assets are not always created. Deficit-financed development fails to promote equity and rather creates a situation where poverty alleviation programs do not make the intended thrust on poverty levels in the country.

Against this grim scenario, one might be inclined to consider the excesses of fiscal and monetary policy quite justified in so far as these are tied to antipoverty measures. The pre-poll extravagance in Tamil Nadu and the Central's generosity towards those affected be floods in Punjab on the one hand and announcement of loan waivers by the Governments of Haryana and Maharashtra and loan meal as organized every now and then by public sector banks on the other may be deemed a response to considerations promoting the greatest happiness of the greatest number.

The growing fiscal imprudence has serious policy implications but advocates of humane governance might want this to be excused on grounds of poverty alleviation. State Governments writing off farm and other loans and the holding of loan melas have grave repercussions for monetary control. Still, to the extent that these benefit the poor, the demand can justifiably be mode that these again should be excused. Deficit financing on the scale resorted to quite obviously is inflationary.

Having said all this, however, we must concede that considerations of fiscal and monetary providence cannot be thrown to the winds. In the overall, the demands of economic justice are not allowed to dictate terms to the exclusion of the norms of discipline. One can of course argue that there can be no alternative to fiscal improvidence in a situation where poverty and economic disparities are growing. Similarly, one can forcefully support the case for the banking sector assuming an increasing social burden because the end poverty alleviation-justified the means. But, these are measures that only seem to promote humane governance in economic terms and not really do so.

A balance must be struck between the demands of poverty alleviation and those of fiscal and monetary prudence. While humane governance should be high on the list of national priorities, a want of discipline in fiscal and monetary policy cannot be condemned on its account.

There should be a limit to Governmental extravagance and the basic norms of fiscal and monetary prudence respected. As for humane governance, it is time the political leadership revised that extravagance and bonanza were no way to promote this. Financial resources productively spent can make a donation to poverty that reckless waste cannot and will not.

We will have to consider fundamental changes in the monetary, fiscal and other economic policies, so that the Government's unbridled powers to garner nation's resources and use them for the benefit of the privileged few are curbed and a productive and an equitable development map prevail in the economy.

\section{ACKNOWLEDGMENT}

Both the authors would like to thank the Principal and the staff of the Commerce Department of JSHPG College, Amroha, U.P., India. Their cooperation in the making of this paper is highly acknowledged. Special thanks to Prof. P.K. Jain for his assistance and guidance throughout. We would also like to thank our son Ritvik Sharma for his encouragement and support.

\section{REFERENCES}

[1] S. Bhattacharya "Financial swap's some Aspects," The Economic Times, p. 5, Dec. 10, 1988

[2] K. S. Ramachandran, "The economic scene link between fiscal and monetary policy," Financial Express, p. 5, Dec. 10, 1988.

[3] K. S. Ramachandran, The Economic Scene-with Fiscal Policy, p. 5, Jan. 21, 1989.

[4] Chakrabarty Committee Report 1985. Committee to review the Monetary System. [Online]. Available: www.rbi.org.in

[5] Indian ETD Repository @ INFLIBNET. [Online]. Available: http://Shodhganga.inflibnet.ac.in

[6] Financial Express Bureau, "RBI in favour of monetary targeting with center," Financial Express, p. 1, Dec. 30, 2010.

[7] R. N. Malhotra, "Fiscal challenge issues in monetary management," The Economic Times, p. 5, Dec. 8, 2010. 
[8] R. N. Malhotra, "II Deficit Financing," The Economic Times, p. 5, Dec. 9, 2010.

[9] R. Chelliah, "Fiscal Policy in Underdeveloped countries with special Reference to India," The Economic Times, p. 2, Jan. 5, 2011.

[10] C. Rangarajan, "Issues in monetary management-I," Financial Express, p. 7, Jan. 10, 2011.

[11] C. Rangarajan, "Issues in monetary management-II," Financial Express, p. 7, Jan. 11, 2011.

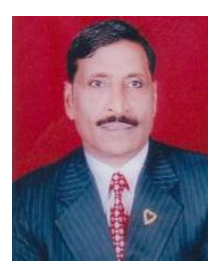

Sudhansh Kumar Sharma was born in Dhampur, Uttar Pradesh, India on February 3,1957. He is amongst the few D. Litt. degree holders in the country, the first from MJP Rohilkhand University, Bareilly. He completed his master's degree in commerce in 1977 and master's degree in economics in 1979, both from MJP Rohilkhand University, Bareilly, Uttar Pradesh, PIN 243001 India. His interest in research work made him get a Ph.D. degree in labour problems from the same university in 1982. He was awarded a doctor of letters degree in public finance in 1994, also from the same university.

$\mathrm{He}$ has been teaching in the Department of Commerce for over 30 years. $\mathrm{He}$ is presently an associate professor and the head of the Commerce Department in Jagdish Saran Hindu Post Graduate College, Amroha, Uttar Pradesh, PIN 244221 India. He is the co-author of Financial Accounting (Meerut, Uttar Pradesh, India: Kedarnath Ramanath Publications, 2004), Management Accounting (Meerut, U. P. India: Swati Publications, 2008) and Income Tax (Meerut, U. P. India: Swati Publications, 2011). He has published 31 research papers in major journals in India and abroad. Also, 23 research scholars have pursued their Ph.D. degrees under him. He is highly devoted to teaching and research work and has a major interest in Marketing and Management related fields.

Dr. Sharma is a life member of the Indian Accounting Conference. Presently, he is the convenor of the Board of Studies of the vocational subject Advertising, Sales Promotion and Sales Management in MJP Rohilkhand University, Bareilly, India. He was also a member of the Board of Studies of Commerce in the same university.

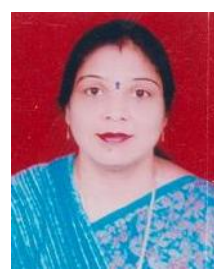

Beena Sharma was born in Anand, Gujarat, India on February 20,1974. She topped the MJP Rohilkhand University, Bareilly, Uttar Pradesh, PIN 243001 India in her master's degree in commerce in 1998. She was awarded her $\mathrm{Ph} . \mathrm{D}$. degree in commerce in 2001. Because of her keen interest in studies, she further pursued her bachelor's and master's degrees in education in 2004 and 2005 respectively. She went on to get a Ph.D. degree in Education in 2009. All these degrees were awarded by the same university.

She started teaching from 2000 as a lecturer in the Department of Commerce, Jagdish Saran Hindu Post Graduate College, Amroha, Uttar Pradesh, PIN 244221 India. Presently she is an assistant professor in the same college, in the same field itself. She is the author of Working and Achievements of Employees' State Insurance Co-operation (Bina, Madhya Pradesh, India: Aditya Publishers, 2003). She has been a part of over 35 National and International Seminars. More than 16 national and international journals have had her research papers printed. Her major interest lies in the field of Accounting and Statistics.

Dr. Sharma has been awarded many prizes for her meritorious contribution in the field of education. She is a prominent writer and often writes for educational journals and newspapers. 